\title{
Qol Resistance in Fusicladium carpophilum Populations from Almond in California and Evaluation of Molecular Resistance Mechanisms
}

Y. Luo, L. Hou, H. Förster, and J. E. Adaskaveg, Department of Plant Pathology and Microbiology, University of California, Riverside 92521

\begin{abstract}
Luo, Y., Hou, L., Förster, H., and Adaskaveg, J. E. 2013. QoI resistance in Fusicladium carpophilum populations from almond in California and evaluation of molecular resistance mechanisms. Plant Dis. 97:1322-1330.

Disease management failures have been reported in California for almond scab caused by Fusicladium carpophilum following quinone outside inhibitor (QoI) applications. Resistance in the pathogen populations was found to be common and at high incidence in the major almond-growing regions beginning in 2003, 4 years after registration of azoxystrobin on this crop. Two levels of azoxystrobin resistance, moderate and high, were identified with $50 \%$ effective concentration $\left(\mathrm{EC}_{50}\right)$ values between 0.15 and $10 \mu \mathrm{g} / \mathrm{ml}$ or $>40 \mu \mathrm{g} / \mathrm{ml}$, respectively. Reference isolates collected before resistance was detected had $\mathrm{EC}_{50}$ values $<0.05 \mu \mathrm{g} / \mathrm{ml}$. High-resistance was associated with a G143A mutation in the mitochondrial cytochrome $b$ gene. For the less commonly found moderately resistant isolates, no mutations in the gene were detected between codons 122 and 212 . Using primers targeting the G143A mutation or the cytochrome $b$ gene of all $F$. carpophilum isolates in quantitative polymerase chain reaction (qPCR)

analyses, the frequency of highly resistant isolates was accurately determined in mixtures of conidia with selected ratios of sensitive and resistant isolates. The frequency of high resistance in bulked samples of scab lesions, however, was generally underestimated compared with in vitro testing of fungicide sensitivity of fungal isolates from the same lesions. Competition experiments using conidial suspensions demonstrated stability of the highly resistant genotype in the presence of different amounts of sensitive and moderately resistant genotypes. Analysis of covariance of linear regressions of cycle threshold values on DNA concentrations derived from qPCR amplifications using two primer pairs for cytochrome b alleles with and without the G143 mutation showed that several isolates differed in their slopes and midpoints. Thus, heteroplasmy of mitochondrial-inherited QoI resistance is suggested as a likely cause for incongruence in estimating resistance frequencies using the two methods.
\end{abstract}

Almond scab, caused by Fusicladium carpophilum (Thüm.) Oudem, is a common and widespread fungal disease in California almond growing regions (18). The sexual stage of the pathogen, Venturia carpophila E.E. Fisher, has been described on overwintered apricot leaves in Australia (4) but has not been found in California. In the spring, primary conidial inoculum is produced on overwintering twig infections and is wind-disseminated to newly developing leaves, shoots, and fruit. Symptoms develop slowly over weeks and become visible as dark gray to olivaceous spots in late spring and summer. Economic loss may result when trees defoliate prematurely from severe leaf infections. Fruit infections contribute to the production of additional inoculum during the season but they do not result in fruit drop or reduced nut quality. The disease is found especially in locations with high humidity, long wetness periods (slow drying times), and poor air circulation (e.g., along rivers and in low spots where dew accumulates and orchards where soils require frequent irrigation schedules).

Management of almond scab is done with dormant treatments of liquid lime sulfur or, more recently, with copper-agricultural oil mixtures to delay and reduce sporulation of twig lesions (5) and within-season treatments to prevent new infections. Before the introduction of the quinone outside inhibitor (QoI) fungicides azoxystrobin, trifloxystrobin, and pyraclostrobin, multi-site modeof-action fungicides such as captan, ziram, maneb, or wettable sulfur were applied during the petal fall period during leaf emergence and commonly prior to spring rains to manage the disease. Additionally, the single-site mode-of-action methyl ben-

Corresponding author: J. E. Adaskaveg, E-mail: jim.adaskaveg@ucr.edu

Accepted for publication 12 April 2013.

http://dx.doi.org/10.1094/PDIS-12-12-1211-RE

(C) 2013 The American Phytopathological Society zimidazole carbamate fungicides (e.g., benomyl and thiophanatemethyl) were also used. Resistance against these latter fungicides, however, developed in the pathogen populations in different regions (18). Due to their superior efficacy and low-rate usage, QoI fungicides were used extensively since 1999 and, for several years, scab was considered a minor disease in California almond production. Failures to successfully manage almond scab with QoI compounds were first reported in 2003 (J. E. Adaskaveg, unpublished). Our preliminary surveys of $F$. carpophilum populations indicated that the pathogen had developed resistance against the QoI class of fungicides at several locations (6). One objective of the current study was to verify that resistance was responsible for treatment failures after application of QoI compounds at additional orchard locations in the major almond growing regions of California and to obtain information on the fitness of resistant isolates. This information could be used in recommendations for a change in chemical disease management strategies that would include the rotation of QoI compounds with fungicides of different modes of action where QoI resistance is not present or the exclusive use of alternative compounds in the presence of resistance.

Another objective of this study was to elucidate the molecular mechanism of QoI resistance in $F$. carpophilum. QoI fungicides bind to the membrane protein that forms the core of the mitochondrial $b c l$ complex in the respiratory chain and block the electron transfer process in the respiration pathway, leading to energy deficiency due to lack of adenosine triphosphate $(2,10)$. Resistance to QoI fungicides has been found in many fungal plant pathogens and the molecular mechanisms of resistance have been investigated extensively $(3,9,10,12,14)$. For example, in studies on Alternaria spp. (17), Mycosphaerella fijiensis (21), Penicillium digitatum (23), Podosphaera fusca and Pseudoperonospora cubensis (11), Blumeria (Erysiphe) graminis (22), and V. inaequalis (24), it was shown that an amino acid substitution at codon 143 in the cytochrome $b$ gene from glycine to alanine (i.e., G143A) resulted in high resistance to QoI fungicides. By 2008, the G143A mutation had been detected in resistant isolates of more than 20 fungal species (3). 
Additional amino acid substitutions leading to resistance, such as a change from phenylalanine to leucine at position 129 (i.e., F129L) or a change from glycine to arginine at position 137 (i.e., G137R), have been found in other fungi but the level of resistance is lower than for the G143A substitution $(9,10,21)$. Cross-resistance among other QoI fungicides has been observed with both the G143A and F129L mutations (14). Thus, a molecular analysis of QoI resistance in F. carpophilum was conducted. Specific primers targeting the resistance mutation were developed and evaluated if these could be used in quantitative polymerase chain reaction (qPCR) assays to rapidly determine the incidence of resistance at a specific orchard location.

\section{Materials and Methods}

Fungal isolates. Symptomatic almond fruit and leaves were collected from field sites in Colusa, Butte, and Glenn Counties in the Sacramento Valley and in Stanislaus and Kern Counties in the San Joaquin Valley between 2006 and 2010. These areas comprise the major almond-growing regions in California. Isolations of $F$. carpophilum were conducted using standard procedures. Lesions were surface-sterilized for $1 \mathrm{~min}$ using sodium hypochlorite at 400 $\mu \mathrm{g} / \mathrm{ml}$, rinsed with sterile water, and plated onto potato dextrose agar (PDA; Difco Laboratories) amended with rifampicin (Sigma Aldrich) at $20 \mu \mathrm{g} / \mathrm{ml}$ and ampicillin (Sigma-Aldrich) at $130 \mu \mathrm{g} / \mathrm{ml}$. Plates were incubated at $24^{\circ} \mathrm{C}$. Isolates were single spored by streaking out conidial suspensions and culturing of single colonies. Fungal isolates were identified based on cultural and microscopic characteristics. Between 4 and 40 isolates of $F$. carpophilum were obtained from a single orchard site and a total of 237 isolates were collected for this study. Five isolates of the pathogen were available from collections conducted between 1996 and 2001. These were used as references to determine the sensitivity of the pathogen prior to the development of QoI resistance in commercial orchards.

Determination of azoxystrobin and trifloxystrobin sensitivity in isolates of $\boldsymbol{F}$. carpophilum. The spiral gradient dilution (SGD) method was used to determine $50 \%$ effective concentration $\left(\mathrm{EC}_{50}\right)$ values for the QoI fungicide azoxystrobin against conidial germination. Assays were conducted as described previously (7). Briefly, stock concentrations of azoxystrobin (Abound 2.08F; Syngenta Crop Protection), 100 or $5,000 \mu \mathrm{g} / \mathrm{ml}$, were prepared in sterile water to obtain radial concentration gradients of 0.006 to $0.5 \mu \mathrm{g} / \mathrm{ml}$ or 0.3 to $>20 \mu \mathrm{g} / \mathrm{ml}$, respectively. These were applied to PDA amended with salicylhydroxamic acid (prepared in 50\% ethanol and added to the cooled media; Sigma Aldrich) at $100 \mu \mathrm{g} / \mathrm{ml}$ in 15$\mathrm{cm}$ petri dishes using a spiral plater (Autoplate 4000; Spiral Biotech) in the exponential deposition mode of deposition. Plates were inoculated with $10-\mu \mathrm{l}$ droplets of conidial suspensions $\left(5 \times 10^{5}\right.$ to 5 $\times 10^{6}$ conidia $\left./ \mathrm{ml}\right)$ that were prepared in $0.01 \%$ (vol/vol) Triton X100 surfactant (Sigma Aldrich) from 7- to 10-day old PDA cultures. Droplets were streaked radially along the concentration gradient. After incubation at $25^{\circ} \mathrm{C}$ for 16 to $18 \mathrm{~h}$, conidial germination was evaluated under a microscope using a $\times 16$ objective. A conidium was considered germinated if the germ tube was at least twice the diameter of the conidium. The location along the spore streak where germination was inhibited by $50 \%$ was determined by counting conidia within the field of view and was marked on the bottom side of the plate. The 1-day incubation option was used in the SGE software (Spiral Biotech) for the calculation of local fungicide concentrations. All isolates were evaluated in two independent experiments. Isolates with $\mathrm{EC}_{50}$ values for azoxystrobin of $<0.05 \mu \mathrm{g} / \mathrm{ml}, 0.15$ to $15 \mu \mathrm{g} / \mathrm{ml}$, or $>40 \mu \mathrm{g} / \mathrm{ml}$ were considered sensitive, moderately resistant, or highly resistant, respectively. A subset of 8 moderately resistant and 10 highly resistant isolates was also tested for their sensitivity against trifloxystrobin (Flint WG; Bayer Crop Science) using the same procedure.

DNA extraction. In total, 30 isolates of $F$. carpophilum were used to evaluate the molecular mechanism of QoI resistance. These comprised 5, 7, and 18 isolates rated as sensitive, moderately resistant, or highly resistant, respectively, against azoxystrobin and were randomly selected from the collection (Table 1). For DNA extraction, cultures were grown on PDA at $25^{\circ} \mathrm{C}$ for 7 days. Conidia and hyphal fragments of each isolate were collected into an extraction tube by scraping an agar area of approximately $2 \mathrm{~cm}^{2}$ with a sterile spatula. The FastDNA spin kit (MP Biomedicals LLC) was used following the instructions of the manufacturer. DNA preparations of each sample were resuspended in $50 \mu \mathrm{l}$ of sterile distilled water and were diluted 10 -fold before PCR amplification. For DNA extraction from scab lesions, lesions were excised from diseased almond fruit using a sterilized scalpel. Ten lesions (each approximately 2 by 2 by $1 \mathrm{~mm}$ in size) were collected into each extraction tube and DNA extraction was done as described for conidia above, except that two to three additional washes with Salton Wash number 1 of the FastDNA spin kit were done.

Sequencing of the partial cytochrome $b$ gene. DNA sequences of the partial cytochrome $b$ gene from four fungal species were obtained from GenBank: Alternaria alternata (accession number DQ209283.1), B. graminis f. sp. tritici (accession number AF343441.1), M. graminicola (accession number AY247413.1), and Penicillium digitatum (accession number FM177893.1). Sequences were aligned using ClustalW2 (http://www.ebi.ac.uk/ Tools/clustalw2/index.html) and a degenerate primer pair was designed: CCF (5'-YACWGCTTCAGCTTTCTTYTTYTTAGT-3') and CCR (5'-AAMAYWATAATRAATAAAAATATWGTT-3'). This primer pair was used to amplify a DNA fragment approximately $580 \mathrm{bp}$ in size that represented the partial cytochrome $b$ gene (codon 122 to codon 212) from two azoxystrobin-sensitive isolates of $F$. carpophilum (isolates 3550 and 3554), three moderately resistant isolates (isolates 3105,3106 , and 3547), and six highly resistant isolates $(3099,3104,3548,3549,3551$, and 3686). Amplifications were done in a PTC-100 thermocycler (MJ Research) in 25- $\mu \mathrm{l}$ volumes containing $1 \mu \mathrm{l}$ of DNA extract, $2.5 \mu \mathrm{l}$ of 10× PCR buffer, $0.25 \mu \mathrm{l}$ of dNTPs (10 mM each), $0.25 \mu \mathrm{l}$ of bovine serum albumin (BSA) (nonacetylated; $10 \mathrm{mg} / \mathrm{ml}$; SigmaAldrich), $1 \mu \mathrm{l}$ of each primer $(10 \mu \mathrm{M}), 0.25 \mu \mathrm{l}$ of Taq DNA polymerase (New England Biolabs), and $17 \mu \mathrm{l}$ of sterile distilled water. A touch-down amplification protocol was as follows: initiation at $94^{\circ} \mathrm{C}$ for $5 \mathrm{~min}$; followed by 20 cycles of $94^{\circ} \mathrm{C}$ for 1 min, $50^{\circ} \mathrm{C}$ for 1 min with a decrease of $0.5^{\circ} \mathrm{C}$ in each cycle, and $72^{\circ} \mathrm{C}$ for $1 \mathrm{~min}$; followed by 20 cycles of $94^{\circ} \mathrm{C}$ for $1 \mathrm{~min}, 40^{\circ} \mathrm{C}$ for $1 \mathrm{~min}$, and $72^{\circ} \mathrm{C}$ for $1 \mathrm{~min}$. The final extension step was at $72^{\circ} \mathrm{C}$ for $5 \mathrm{~min}$. PCR products were purified using ExoSAP-IT (USB Corporation) and sequenced at the Core Instrumentation Facility of the University of California Riverside Institute for Integrative Genome Biology. DNA sequences were translated to amino acid sequences using EMBOSS Transeq (http://www.ebi.ac.uk/ emboss/transeq/) and amino acid sequences were aligned using ClustalW2 to detect mutant positions, with a focus on amino acid position 143 .

Primer design to target azoxystrobin resistance or the partial cytochrome $\boldsymbol{b}$ gene from all isolates of $\boldsymbol{F}$. carpophilum. Based on mismatches at codon 143 (i.e., a G143A mutation) between the amino acid sequences of azoxystrobin-sensitive and highly resistant isolates, primer CCRF1 (5'-GGTCAAATGAGTTTATGA GC-3') was designed to target this mutation. Primer CCR1-2 (5'TGAAACACCCAGAGGATTACC-3') was used as the reverse primer in the amplifications. As a control, to amplify DNA from all isolates of $F$. carpophilum, forward primer CCF1-2 (5'ATGGCTACTGCCTTTTTAGGA-3') was designed that started at codon 125. For this forward primer, CCR1-2 was also used as the reverse primer.

The specificity of primer pair CCRF1/CCR1-2 was tested on the 30 isolates of $F$. carpophilum in Table 1 that exhibited different levels of sensitivity to azoxystrobin. PCR reactions were conducted in 25- $\mu$ l volumes that included $12.5 \mu \mathrm{l}$ of PCR supermix (Promega Corporation), $0.75 \mu \mathrm{l}$ each of primer $(10 \mu \mathrm{M}), 8.75 \mu \mathrm{l}$ of distilled $\mathrm{H}_{2} \mathrm{O}$, and $3 \mu \mathrm{l}$ of template DNA $(10 \mathrm{ng} / \mu \mathrm{l})$. The following PCR conditions were used: initiation at $94^{\circ} \mathrm{C}$ for $5 \mathrm{~min}$, followed by 35 cycles of $94^{\circ} \mathrm{C}$ for $1 \mathrm{~min}, 65^{\circ} \mathrm{C}$ for $1 \mathrm{~min}$, and $72^{\circ} \mathrm{C}$ for $1 \mathrm{~min}$. The final extension step was at $72^{\circ} \mathrm{C}$ for $5 \mathrm{~min}$. PCR products were 
separated in $1.5 \%$ agarose gels. To evaluate the specificity of primer pair CCF1-2 /CCR1-2 for F. carpophilum, DNA of five isolates each of Botrytis cinerea, Monilinia fructicola, Alternaria spp., and Botryosphaeria dothidea were used. DNA was extracted as described above. PCR conditions were the same as for primers CCRF1/CCR1-2.

Development of a qPCR assay to quantify azoxystrobin-resistant isolates with the G143A mutation. Amplifications for qPCR were performed in a Bio-Rad MyiQ single-color real-time PCR system (Bio-Rad Laboratories, Inc.) using SYBR Green I fluorescent dye detection. Amplifications were conducted in $25-\mu l$ volumes containing $3 \mu \mathrm{l}$ of template DNA, $2.5 \mu \mathrm{l}$ of $10 \times$ PCR buffer, $0.25 \mu \mathrm{l}$ of dNTPs (10 mM each), $0.25 \mu \mathrm{l}$ of BSA, $2 \mu \mathrm{l}$ of SYBR Green (SYBR Green I nucleic acid gel stain; 10,000x concentrate in dimethyl sulfoxide diluted 1:5000 with $10 \mathrm{mM}$ Tris $\mathrm{HCl}, \mathrm{pH} 7.5$; Invitrogen), $0.5 \mu \mathrm{l}$ of each forward and reverse primer $(10 \mu \mathrm{M}), 0.25 \mu \mathrm{l}$ of Taq DNA polymerase, and $15.75 \mu \mathrm{l}$ of sterile distilled water. The following amplification parameters were used: an initial denaturation step for $30 \mathrm{~s}$ at $95^{\circ} \mathrm{C}$, followed by 35 cycles of $95^{\circ} \mathrm{C}$ for $15 \mathrm{~s}, 65^{\circ} \mathrm{C}$ (for both $\mathrm{CCF} 1-2 / \mathrm{CCR} 1-2$ and CCRF1/CCR1-2 primer pairs) for $25 \mathrm{~s}, 72^{\circ} \mathrm{C}$ for $30 \mathrm{~s}$, and $72^{\circ} \mathrm{C}$ for $1 \mathrm{~min}$. Under these conditions, fluorescence was detected and quantified at a temperature above the denaturation temperature of primer-dimers. After amplifications were completed, melting curves were obtained to confirm that the fluorescence signal came from the targeted product and that only minimal contamination of primer dimers was present. The temperature at the peak of the melt curve was used to confirm the correct PCR product for each sample in each run.

To develop a standard curve for the quantitative detection of azoxystrobin-resistant isolates harboring the G143A mutation, 10- fold serial dilutions from $3 \mathrm{fg}$ to $3 \mathrm{ng}$ of DNA from the highly resistant isolate 3551 were used in $\mathrm{QPCR}$ amplifications with primer pair CCRF1/CCR1-2. To create standard curves for the quantitative detection of all isolates of $F$. carpophilum, 10-fold serial dilutions from $3 \mathrm{fg}$ to $3 \mathrm{ng}$ of DNA from the azoxystrobin-sensitive isolate 3105 were used in amplifications with primer pair CCF12/CCR1-2. Standard curves were constructed with the cycle threshold $\left(\mathrm{C}_{\mathrm{T}}\right)$ plotted on the $\mathrm{x}$-axis and DNA concentration plotted on the y-axis. To verify the accuracy of DNA quantification, $1 \mathrm{ng}$ of DNA of isolates 3105 or 3551 was amplified using primer pairs CCF1-2/CCR1-2 or CCRF1/CCR1-2, respectively.

For each sample to be quantified, two qPCR amplifications with four replicates each were conducted in the same run, one targeting the resistance allele G143A using primer pair CCRF1/CCR1-2 and another one for the nonspecific detection of $F$. carpophilum using primer pair CCF1-2/CCR1-2. DNA quantities were calculated from $\mathrm{C}_{\mathrm{T}}$ values from each of the corresponding standard curves. The frequency (\%) of the G143A allele in each sample (FA) was then calculated by the formula $F A=\left(Q_{A} / Q_{G}\right) \times 100$, where $Q_{A}$ is the amount (fg) of the G143A allele and $\mathrm{Q}_{\mathrm{G}}$ is the total amount (fg) of $c y t b$ template in the sample. This experiment was done twice.

To quantify the frequency of spores with the G143A allele in mixed-pathogen populations by qPCR, two conidial suspensions were prepared in the CLS-Y reagent of the FastDNA spin kit: one with equal amounts $\left(2 \times 10^{5} \mathrm{conidia} / \mathrm{ml}\right)$ of five azoxystrobinsensitive isolates (isolates 953, 3082, 3550, 3105, and 3106; conidial suspension $\mathrm{S})$ and one with equal amounts $\left(2 \times 10^{5}\right.$ conidia/ml $)$ of five isolates highly resistant to azoxystrobin (isolates 3099, 3104, 3799, 3835, and 3822; conidial suspension R). Mixed suspensions of $\mathrm{S}$ and $\mathrm{R}$ were prepared that contained $0.00,0.01,0.05$, $0.10,0.20,0.30,0.40,0.50,0.60,0.70,0.80,0.90,0.95,0.99$, and

Table 1. Isolates of Fusicladium carpophilum used for molecular characterization of azoxystrobin sensitivity in this study

\begin{tabular}{|c|c|c|c|c|c|}
\hline QoI group, isolate & $\begin{array}{c}\text { Origin } \\
\text { (county of California) }\end{array}$ & $\begin{array}{c}\text { Year of } \\
\text { isolation }\end{array}$ & EC $_{50} \underset{(\mu \mathrm{g} / \mathrm{ml})^{\mathrm{b}}}{\text { azoxystrobin }}$ & Sequence analysis ${ }^{c}$ & Detection of $\mathrm{G} 143 \mathrm{~A}^{\mathrm{d}}$ \\
\hline \multicolumn{6}{|l|}{ Sensitive } \\
\hline 953 & Stanislaus & 1996 & 0.018 & $\ldots$ & - \\
\hline 2380 & Solano & 2001 & 0.016 & $\ldots$ & - \\
\hline 3550 & Butte & 2009 & 0.027 & + & - \\
\hline 3554 & Butte & 2009 & 0.032 & + & - \\
\hline 3672 & Butte & 2009 & 0.036 & $\ldots$ & - \\
\hline \multicolumn{6}{|l|}{ Moderately resistant } \\
\hline 3082 & Butte & 2006 & 0.53 & $\ldots$ & - \\
\hline 3087 & Butte & 2006 & 1.023 & $\ldots$ & - \\
\hline 3093 & Butte & 2006 & 6.15 & $\ldots$ & - \\
\hline 3105 & Butte & 2007 & 1.87 & + & - \\
\hline 3106 & Butte & 2007 & 1.87 & + & - \\
\hline 3069 & Kern & 2006 & 8.96 & $\ldots$ & - \\
\hline 3547 & Kern & 2009 & 0.166 & + & - \\
\hline \multicolumn{6}{|l|}{ Highly resistant } \\
\hline 3092 & Butte & 2006 & $>40$ & $\ldots$ & + \\
\hline 3099 & Butte & 2007 & $>40$ & + & + \\
\hline 3104 & Butte & 2007 & $>40$ & + & + \\
\hline 3551 & Butte & 2009 & $>40$ & + & + \\
\hline 3552 & Butte & 2009 & $>40$ & $\ldots$ & + \\
\hline 3673 & Butte & 2009 & $>40$ & $\ldots$ & + \\
\hline 3799 & Butte & 2006 & $>40$ & $\ldots$ & + \\
\hline 3807 & Butte & 2006 & $>40$ & $\ldots$ & + \\
\hline 3822 & Butte & 2006 & $>40$ & $\ldots$ & + \\
\hline 3835 & Butte & 2006 & $>40$ & $\ldots$ & + \\
\hline 3686 & Glenn & 2009 & $>40$ & + & + \\
\hline 3688 & Glenn & 2009 & $>40$ & $\ldots$ & + \\
\hline 2502 & Kern & 2003 & $>40$ & $\ldots$ & + \\
\hline 2503 & Kern & 2003 & $>40$ & $\ldots$ & + \\
\hline 3548 & Kern & 2009 & $>40$ & + & + \\
\hline 3549 & Kern & 2009 & $>40$ & + & + \\
\hline 3660 & Kern & 2009 & $>40$ & $\ldots$ & + \\
\hline 3668 & Kern & 2009 & $>40$ & $\ldots$ & + \\
\hline
\end{tabular}

\footnotetext{
${ }^{a}$ Quinone outside inhibitor (QoI) sensitivity group.

${ }^{\mathrm{b}}$ Sensitivity to azoxystrobin was determined for conidial germination using the spiral gradient dilution method; $\mathrm{EC}_{50}=50 \%$ effective concentration.

c Sequence analysis of the partial cytochrome $b$ gene.

${ }^{\mathrm{d}}$ Detection of the G143A mutation by polymerase chain reaction.
} 
$1.00 \mathrm{ml}$ of $\mathrm{R}$ suspension in a total of $1 \mathrm{ml}$. Aliquots of $500 \mu \mathrm{l}$ of each suspension were used to extract DNA using the method described above. After qPCR, the frequency of cytochrome $b$ gene copies carrying the G143A allele was determined as described above for each sample. To determine the accuracy of the quantitative G143A detections in the qPCR assay, these frequencies were then regressed on the frequencies of highly resistant conidia in the conidial suspensions that were used for the respective assays. Four replicated amplifications were done for each spore suspension and the experiment was done twice.

Quantification of azoxystrobin resistance in $F$. carpophilum in almond orchards based on fungal growth on amended media and qPCR. Almond fruit with scab lesions were collected from two orchards in Colusa and Kern Counties, CA. Ten scab lesions from each of 7 to 11 fruit per orchard were excised and cut in half. Isolates of $F$. carpophilum were obtained from one-half of each lesion, as described above. Isolates were characterized for their sensitivity to azoxystrobin and, for each fruit, the frequency of highly resistant isolates $\left(\mathrm{EC}_{50}>40 \mu \mathrm{g} / \mathrm{ml}\right)$ was determined based on the total number of isolates obtained from the fruit. The other lesion halves were combined for each fruit and used for DNA extraction and quantification of the G143A allele, as described above.

Competition between QoI-resistant and -sensitive or -moderately resistant isolates in in vitro studies. A mixture of equal amounts of conidia from five isolates highly resistant to azoxystrobin (mixture R; isolates 3014, 3099, 3548, 3551, and 3686) was prepared in $0.01 \%$ Triton X-100 and, similarly, a mixture of equal amounts of conidia from two isolates sensitive (isolates 3550 and 3554) and three isolates with moderate resistance (isolates 3015, 3016, and 3547) to azoxystrobin (mixture S-MR) was prepared. Conidial concentrations were adjusted to $10^{7}$ spores $/ \mathrm{ml}$. These spore suspensions were then mixed to obtain the following three ratios: $20 \%$ mixture $\mathrm{R}+80 \%$ mixture $\mathrm{S}-\mathrm{MR}, 50 \%$ mixture $\mathrm{R}+50 \%$ mixture $\mathrm{S}-\mathrm{MR}$, and $80 \%$ mixture $\mathrm{R}+20 \%$ mixture S-MR. Four replicates of each of these mixtures were done and $20 \mu \mathrm{l}$ was spread onto 9-cm PDA plates with a sterile glass rod. Aliquots of the remaining spore suspensions (i.e., generation 1 of each mixture) were centrifuged and pellets were stored at $-20^{\circ} \mathrm{C}$ for subsequent DNA extraction. After 5 days of incubation at 22 to $25^{\circ} \mathrm{C}$, conidia of each plate were harvested in $1 \mathrm{ml} 0.01 \%$ Triton X-100 (i.e., generation 2 of each mixture), conidial suspensions were spread onto fresh PDA plates, and aliquots were saved for subsequent DNA extraction as described above. This process was repeated until conidial suspensions of the sixth generation were obtained.

DNA extractions from conidia, qPCR reactions (three replicated PCR runs per sample), and calculations for the frequency of cytochrome $b$ gene copies carrying the G143A allele were performed as described above. Mean values of the frequency of the G143A allele for each treatment and for each spore generation as well as standard deviations were graphed for each of the two repeated experiments.

Evaluation of heteroplasmy in isolates highly resistant to azoxystrobin. To evaluate for possible heteroplasmy (i.e., presence of cytochrome b alleles with and without the G143 mutation in the same single-spore isolate), qPCR amplifications were done using serial dilutions of DNA as described above from six highly resistant isolates (i.e., 2503, 3092, 3552, 3660, 3799, and 3807) and primers targeting the G143A allele (CCRF1/ CCR1-2) or the cytochrome $b$ gene of all isolates of $F$. carpophilum (CCF1-2/CCR1-2). Amplicon amounts were then compared by analysis of covariance. Three replicated amplifications were done for each DNA concentration using each primer pair and the experiment was done twice.

Statistical analysis of data. Regression analyses (SAS, version 9.2; SAS Institute) were done to create standard curves for the quantitative detection of the G143A mutation and of the cytochrome $b$ gene of all isolates of $F$. carpophilum. Comparison of frequencies of the G143A allele with known frequencies of QoI resistance in mixed conidial populations, as well as comparison of the frequencies of QoI resistance using qPCR or amended agar assays, was also done by regression analyses.

To evaluate for heteroplasmy, analysis of covariance was done on regressions of amounts of template DNA on $\mathrm{C}_{\mathrm{T}}$ values using mixed-model procedures (SAS). For this, qPCR amplifications of the G143A allele and of the cytochrome $b$ gene for each of six isolates were compared to determine whether the two regression lines had a common slope. Regression lines of isolates with common slopes were also compared for adjusted means (least square means) at the midpoint. Data from repeated experiments did not affect the model, showing no significance at $P<0.05$ in slope and intercept of regressions between two replicated experiments for all isolates and two primer pairs. Thus, data from both experiments were combined and used in the analysis of covariance.

Table 2. Azoxystrobin-sensitivity in populations of Fusicladium carpophilum from almond in California ${ }^{a}$

\begin{tabular}{|c|c|c|c|c|c|}
\hline \multirow[b]{2}{*}{ Year collected } & \multirow[b]{2}{*}{ Location $^{b}$} & \multirow[b]{2}{*}{ Number of isolates evaluated } & \multicolumn{3}{|c|}{ Isolates (\%) } \\
\hline & & & Sensitive $^{c}$ & Moderately resistant $^{\mathbf{d}}$ & Highly resistant ${ }^{\mathrm{e}}$ \\
\hline 1996-2001 & Various & 5 & 100.0 & 0.0 & 0.0 \\
\hline \multirow[t]{4}{*}{2006} & Kern & 8 & 0.0 & 37.5 & 62.5 \\
\hline & Butte 1 & 36 & 0.0 & 2.8 & 97.2 \\
\hline & Butte 2 & 18 & 0.0 & 5.6 & 94.4 \\
\hline & Butte 3 & 18 & 0.0 & 11.1 & 88.9 \\
\hline 2007 & Kern & 40 & 12.5 & 7.5 & 80.0 \\
\hline \multirow[t]{3}{*}{2009} & Kern & 15 & 10.0 & 3.3 & 86.7 \\
\hline & Butte & 16 & 6.2 & 6.3 & 87.5 \\
\hline & Glenn & 9 & 11.1 & 0.0 & 88.9 \\
\hline \multirow[t]{6}{*}{2010} & Butte 1 & 24 & 0.0 & 4.2 & 95.8 \\
\hline & Butte 2 & 11 & 0.0 & 0.0 & 100.0 \\
\hline & Colusa 2 & 4 & 0.0 & 0.0 & 100.0 \\
\hline & Colusa 3 & 12 & 0.0 & 0.0 & 100.0 \\
\hline & Colusa 4 & 13 & 7.7 & 0.0 & 92.3 \\
\hline & Stanislaus & 8 & 0.0 & 0.0 & 100.0 \\
\hline
\end{tabular}

\footnotetext{
a Sensitivity to azoxystrobin was determined based on conidial germination using the spiral gradient dilution method.

${ }^{\mathrm{b}}$ California county and orchard number.

${ }^{\mathrm{c}}$ For sensitive isolates, $50 \%$ effective concentration $\left(\mathrm{EC}_{50}\right)$ values were $<0.05 \mu \mathrm{g} / \mathrm{ml}$.

${ }^{\mathrm{d}} \mathrm{EC}_{50}$ values of moderately resistant isolates ranged from 0.15 to $10 \mu \mathrm{g} / \mathrm{ml}$.

${ }^{\mathrm{e}} \mathrm{EC}_{50}$ values of highly resistant isolates were $>40 \mu \mathrm{g} / \mathrm{ml}$.
} 


\section{Results}

Sensitivity of $\boldsymbol{F}$. carpophilum from almond in California to azoxystrobin and trifloxystrobin. Sensitivity to azoxystrobin of isolates of $F$. carpophilum that were used for molecular studies is shown in Table 1. Five isolates that were collected between 1996 and 2001 and used as reference isolates, before treatment failures following QoI applications were reported, were highly sensitive to azoxystrobin, with $\mathrm{EC}_{50}$ values for conidial germination of less than $0.05 \mu \mathrm{g} / \mathrm{ml}$ (Table 1). Of the isolates obtained from any single location between 2006 and 2010, only up to $12.5 \%$ were determined to be sensitive. The majority of isolates (62.5 to $100 \%$ of the isolates within an orchard) were highly resistant, with $\mathrm{EC}_{50}$ values $>40 \mu \mathrm{g} / \mathrm{ml}$. Moderately resistant isolates with $\mathrm{EC}_{50}$ values between 0.15 and $10 \mu \mathrm{g} / \mathrm{ml}$ were found at higher frequency (incidence 2.8 to $37.5 \%$ among four locations) in 2006 than in 2010 , where only two isolates were found in one of the six orchards surveyed (Table 2). A subset of eight isolates moderately resistant $\left(\mathrm{EC}_{50}\right.$ of 9.0 to $13.0 \mu \mathrm{g} / \mathrm{ml})$ or highly resistant $\left(\mathrm{EC}_{50}>40 \mu \mathrm{g} / \mathrm{ml}\right)$ to azoxystrobin was also found to be moderately $\left(\mathrm{EC}_{50}\right.$ of 2.1 to $\left.4.7 \mu \mathrm{g} / \mathrm{ml}\right)$ or highly $\left(\mathrm{EC}_{50}>40 \mu \mathrm{g} / \mathrm{ml}\right)$ resistant, respectively, to trifloxystrobin.

PCR amplification and sequence analysis of the partial cytochrome $\boldsymbol{b}$ gene from $\boldsymbol{F}$. carpophilum. Degenerate primers CCF1 and CCR1 amplified a DNA fragment approximately $580 \mathrm{bp}$ in size from two isolates of $F$. carpophilum sensitive, three isolates moderately resistant, and six isolates highly resistant to azoxystrobin. The alignment of the deduced amino acid sequences from codon 122 to codon 212 is shown in Figure 1, with the mutation highlighted that was used to design primers. A mutation from glycine to alanine (G143A) occurred at codon 143 in the five highly resistant isolates but not in any of the other isolates. This amino acid change was due to a change in the codon sequence from GGT to GCT. All sequences were identical for the remaining amino acid positions.

Primer specificity to detect the G143A mutation or the partial cytochrome $b$ gene from all isolates of $F$. carpophilum. Using primer pair CCF1-2/CCR1-2, a 272-bp fragment of the cytochrome $b$ gene was amplified from all isolates of $F$. carpophilum (Fig. 2A) but not from isolates of Botrytis cinerea, M. fructicola, Alternaria
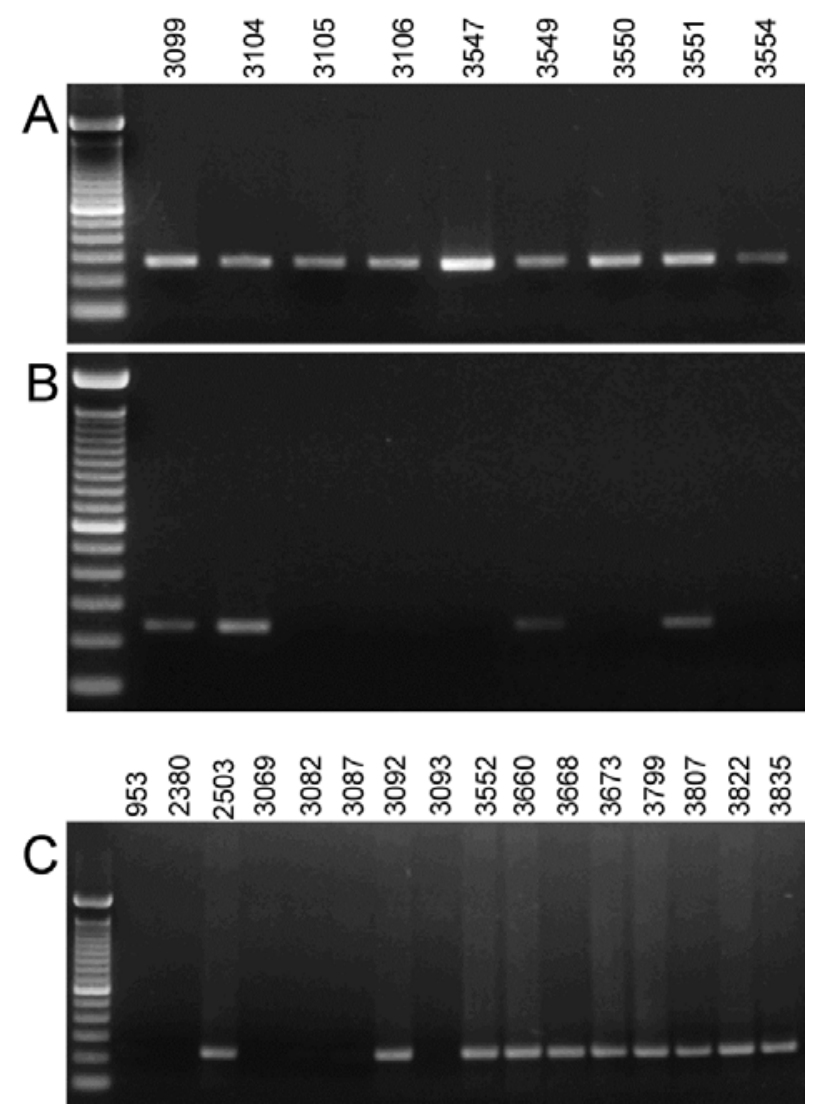

Fig. 2. Evaluation of the specificity of primer pairs A, CCF1-2/CCR1-2 targeting the cytochrome $b$ gene of all isolates of Fusicladium carpophilum and $\mathbf{B}$ and $\mathbf{C}$, CCRF1/CCR1-2 targeting the G143A allele. Isolates with the G143A mutation (2503, 3092, 3099, 3104, 3549, 3551, 3552, 3660, 3668, 3673, 3686, 3799, 3807, 3822 , and 3835 ) show a specific 236 -bp fragment, whereas these isolates and isolates sensitive $(953,2380,3550$, and 3554 ) or moderately resistant to azoxystrobin $(3069,3082,3087,3093,3105,3106$, and 3547) all show a 272-bp fragment (not all isolates are shown for this latter amplification). The first lane in each gel is a 100-bp ladder.

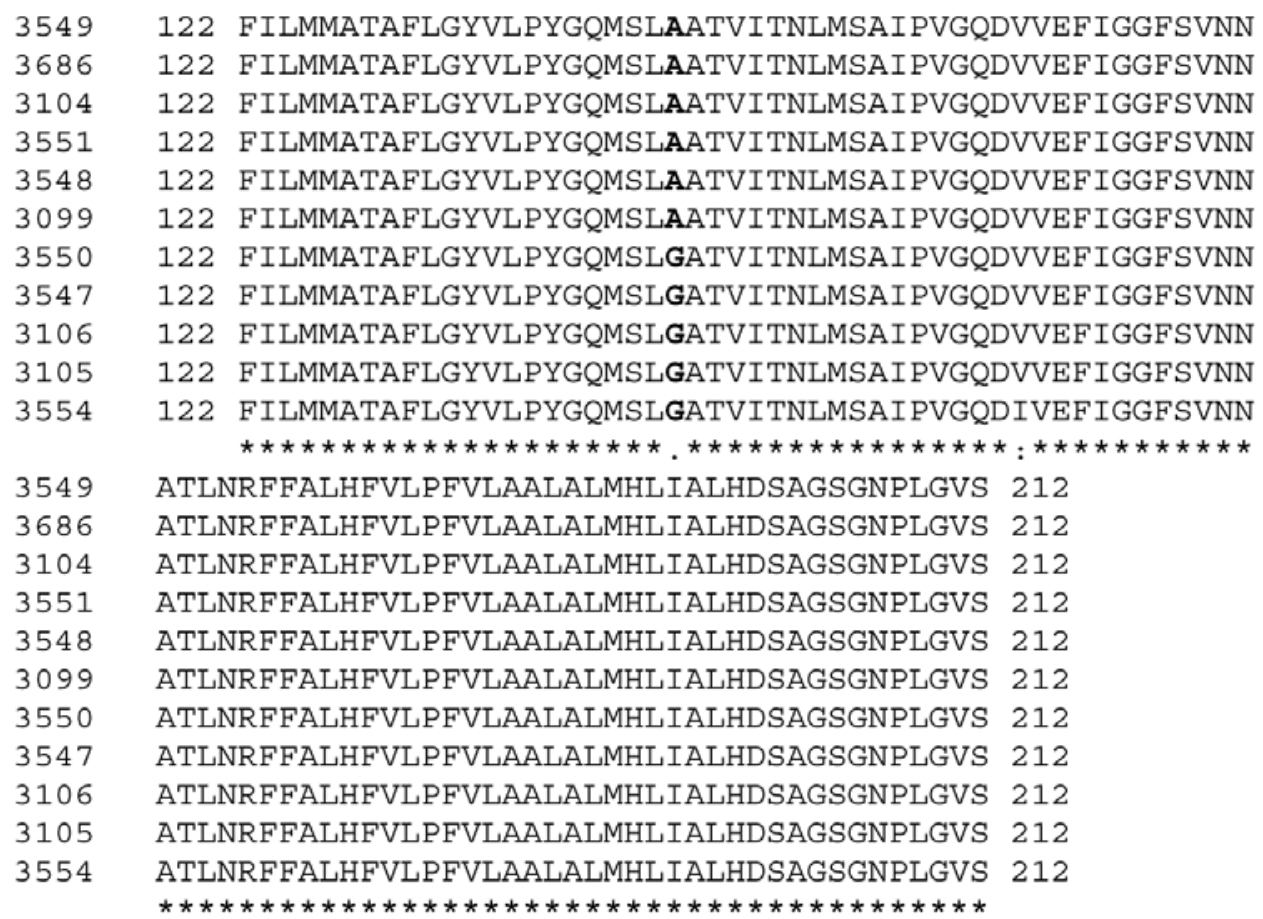

Fig. 1. Alignment of the amino acid sequences of the partial cytochrome $b$ gene (codon 122 to codon 212) for isolates of Fusicladium carpophilum from almond. Isolates 3550 and 3554 are sensitive; isolates 3547,3105 , and 3106 are moderately resistant; and isolates $3099,3104,3548,3549,3551$, and 3686 ) are highly resistant to azoxystrobin. The G143A mutation with a change from glycine to alanine is indicated in bold font. 
spp., and Botryosphaeria dothidea (data not shown). Primer pair CCRF1-2/CCR1-2 that was designed to detect the G143A mutation in F. carpophilum was evaluated in PCR amplifications using template DNA from 30 isolates of the fungus. A DNA fragment of the expected size of $236 \mathrm{bp}$ was amplified only when using DNA from highly resistant isolates (Fig. 2B and C).

Development of a qPCR assay to quantify azoxystrobinresistant isolates with the G143A mutation. Standard curves were constructed by qPCR amplifications from serial dilutions of DNA from isolate 3105 sensitive to azoxystrobin using primer pair CCF1-2/CCR1-2, and from the highly resistant isolate 3551 using primer pair CCRF1/CCR1-2 targeting the G143A mutation (Fig. $3 \mathrm{~A}$ and $\mathrm{B})$. Coefficients of determination $\left(r^{2}\right)$ were both 0.99 , indicating a close relationship between the amount of template DNA and the respective threshold cycle as expressed by the $\mathrm{C}_{\mathrm{T}}$ value. Regression equations for each of the primer pairs were calculated to determine the template amounts of unknown samples.

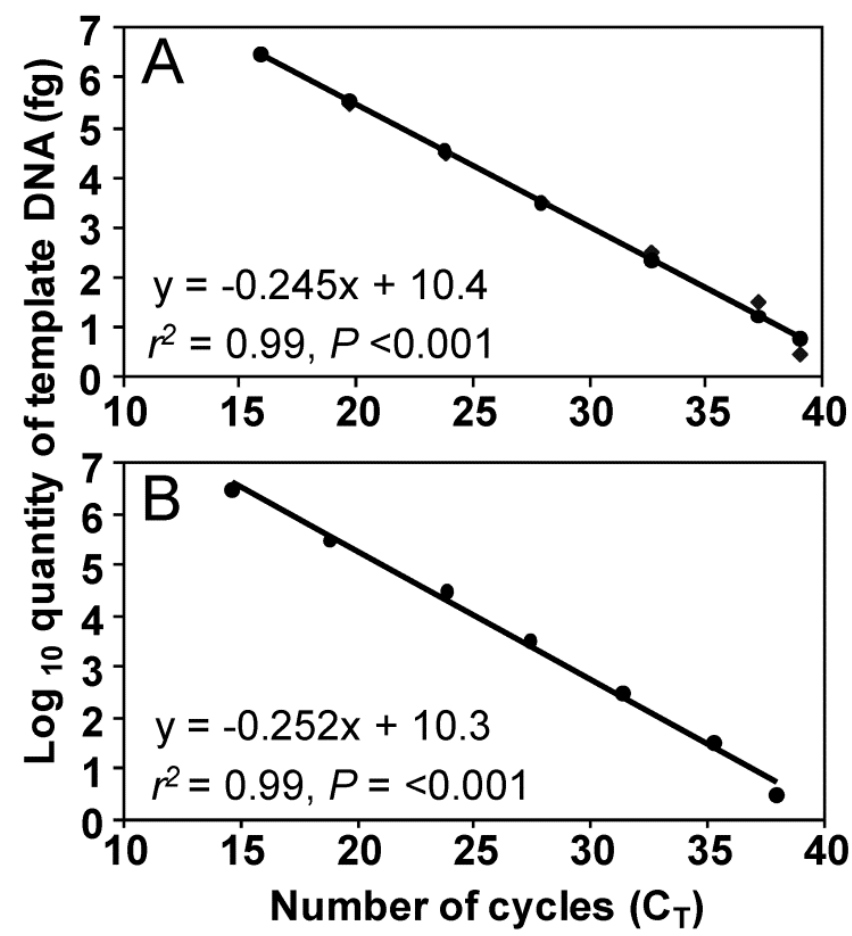

Fig. 3. Standard curves showing the relationship between number of threshold amplification cycles $\left(\mathrm{C}_{T}\right)$ and quantity of DNA [fg $\left.\left(\log _{10}\right)\right]$ using $\mathrm{A}$, primer pair CCF12/CCR1-2 with DNA from isolate 3105 (moderately resistant) or B, primer pair CCRF1/CCR1-2 with DNA from isolate 3551 (highly resistant). Serial dilutions (10x for each step) of DNA were used in quantitative polymerase chain reaction amplifications.

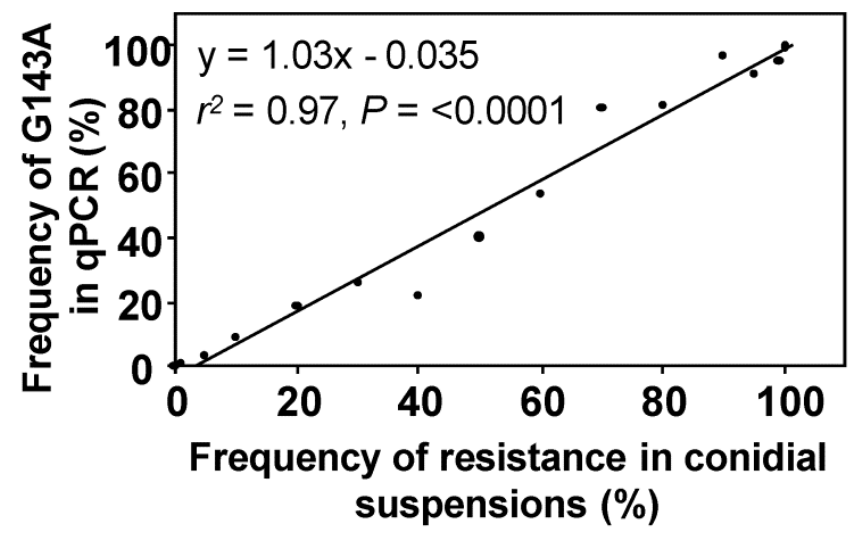

Fig. 4. Correlation between frequency of high-resistance to azoxystrobin in mixtures of conidial suspensions of Fusicladium carpophilum and frequencies of the G143A allele as detected by quantitative polymerase chain reaction (qPCR).
When the frequency of the G143A allele was calculated using template DNA from selected mixtures of sensitive and resistant conidial populations, a linear regression with a high $r^{2}$ value (i.e., 0.997 ) and a probability value of $P \leq 0.0001$ was obtained (Fig. 4), indicating a strong correlation between the actual frequency used in preparing the mixed conidial suspension and the frequency of the G143A allele detected by qPCR.

Quantification of azoxystrobin resistance in $F$. carpophilum in almond orchards based on fungal growth on amended media and qPCR. The frequencies of isolates highly resistant to azoxystrobin (as determined by growth on fungicide-amended agar) graphed against the frequencies of the G143A allele (as determined by $\mathrm{qPCR}$ ) for scab lesions from 7 fruit from the Kern County orchard and 11 fruit from the Colusa County orchard are shown in Figure 5A and B. With very low $r^{2}$ values, correlation between the two methods of assessing frequencies of high-resistance was poor. Except for a few fruit samples, the qPCR method underestimated the frequency of resistance (Fig. 5A and B).

Competition between QoI-resistant and -sensitive or -moderately resistant isolates in in vitro studies. The frequency of the G143A allele in conidial suspensions of $F$. carpophilum was determined after repeated platings of conidial mixtures with selected initial frequencies of highly resistant and sensitive or moderately resistant isolates. Differences in the frequencies were observed between the two experiments conducted that were mostly due to some fluctuations among spore generations (Fig. 6A and B). Overall, however, the frequency of the G143A allele remained stable over six spore generations. For each of the three conidial prepara-

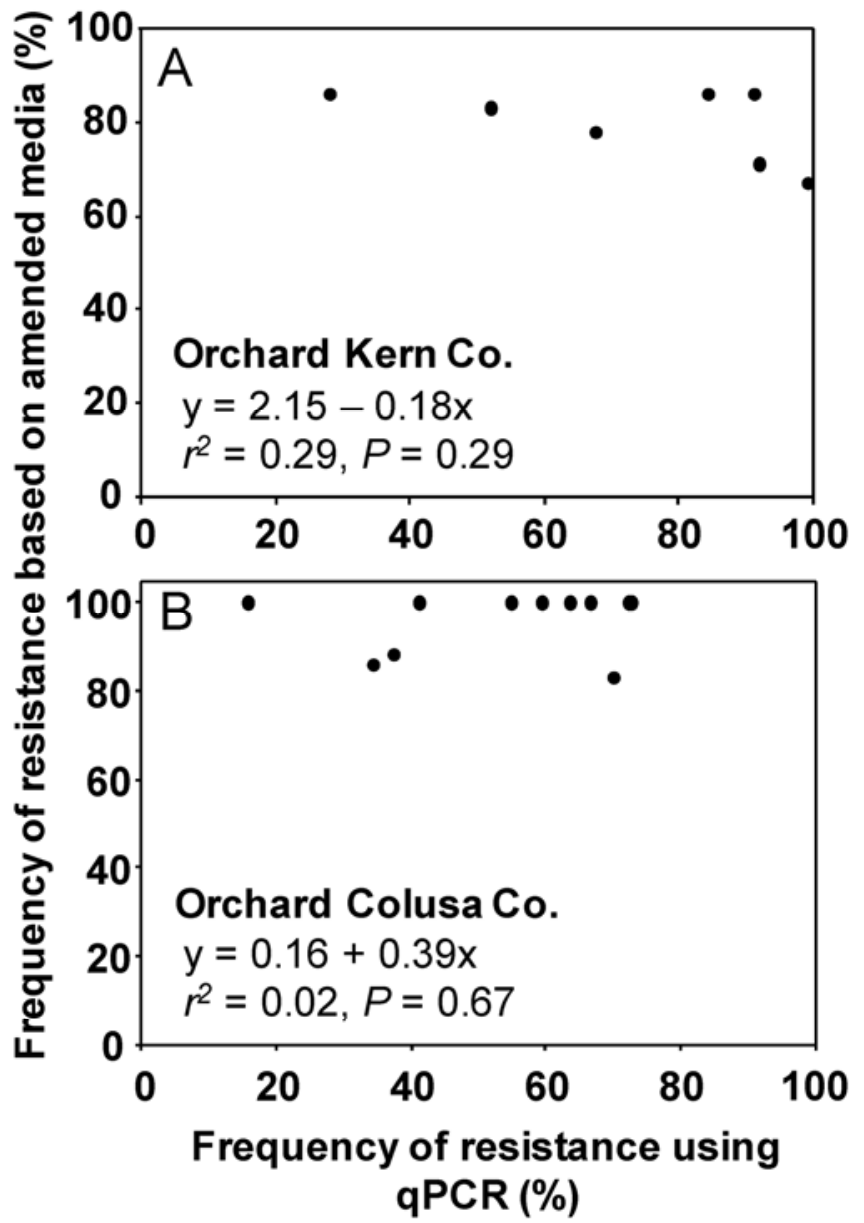

Fig. 5. Quantification of azoxystrobin resistance due to G143A mutation in Fusicladium carpophilum in two almond orchards in A, Kern County and B, Colusa County. Resistance frequencies obtained by fungal growth on fungicide-amended media were regressed on those obtained by quantitative polymerase chain reaction (qPCR). Each data point represents the frequency of azoxystrobin resistance in 10 isolates from one fruit. 
tions, the ratio of highly resistant to sensitive or moderately resistant isolates in the sixth spore generation was similar to the initial preparation.

Evaluation of heteroplasmy in isolates highly resistant to azoxystrobin. Analysis of covariance of linear regressions of $C_{T}$

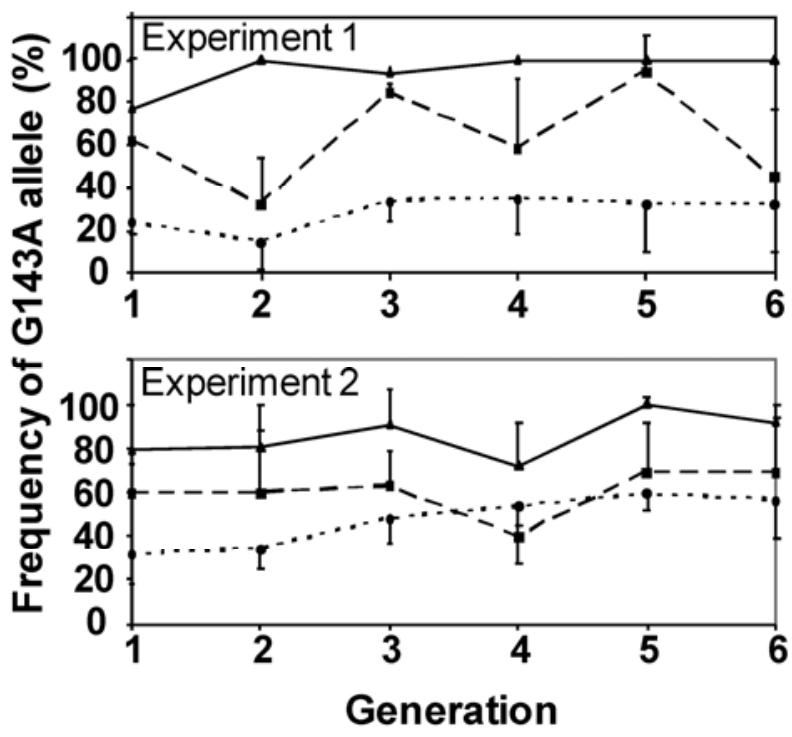

Fig. 6. Frequency of the $\mathrm{G} 143 \mathrm{~A}$ allele as determined by quantitative polymerase chain reaction in conidial suspensions of Fusicladium carpophilum over six successive platings on potato dextrose agar. Three conidial suspensions were prepared initially with frequencies of highly resistant conidia of $20 \%$ (dotted line), $50 \%$ (dashed line), or $80 \%$ (solid line) in generation 1 and plated over six generations. Each data point represents the mean value from four replicated samples per treatment, with three amplifications each. values on DNA concentrations derived from qPCR amplifications using two primer pairs for six isolates highly resistant to azoxystrobin indicated that the two regression lines for three isolates (i.e., 3552, 3660, and 3807) had slopes and midpoints not significantly different $(P>0.2)$ from each other (Fig. 7; Table 3). Slopes of the regression line pairs for each of three other isolates (i.e., 2503, 3092, and 3799), however, were significantly different $(P \leq 0.003)$, indicating that different amounts of amplicons were generated using the two primer pairs. In each case, higher amounts of amplicon were present using primer pair CCF1-2/CCR1-2 that targets the cytochrome $b$ gene of all isolates of $F$. carpophilum than using primer pair CCRF1/CCR1-2 that targets the G143A allele.

\section{Discussion}

QoI resistance was found to be common in isolates of $F$. carpophilum collected from the major almond-growing regions of California between 2006 and 2010. The incidence of resistance generally was very high in the pathogen populations. Only a few reference isolates were available from before the extensive use of

Table 3. $P$ values for slopes and mid-points of pairwise comparisons of regression models of cycle threshold values on DNA concentrations using primer pairs CCF1-2/CCR1-2 and CCRF1/CCR1-2 for each of six highly resistant isolates of Fusicladium carpophilum

\begin{tabular}{lcc}
\hline & \multicolumn{2}{c}{$\boldsymbol{P}$ values } \\
\cline { 2 - 3 } Isolate & Slope & Midpoint $^{\mathrm{a}}$ \\
\hline 3552 & 0.211 & 0.284 \\
3660 & 0.905 & 0.643 \\
3807 & 0.471 & 0.315 \\
3092 & $<0.0001$ & $\mathrm{ND}$ \\
2503 & $<0.0001$ & $\mathrm{ND}$ \\
3799 & 0.003 & $\mathrm{ND}$ \\
\hline
\end{tabular}

${ }^{\mathrm{a}} \mathrm{ND}=$ not determined because slopes were significantly different.
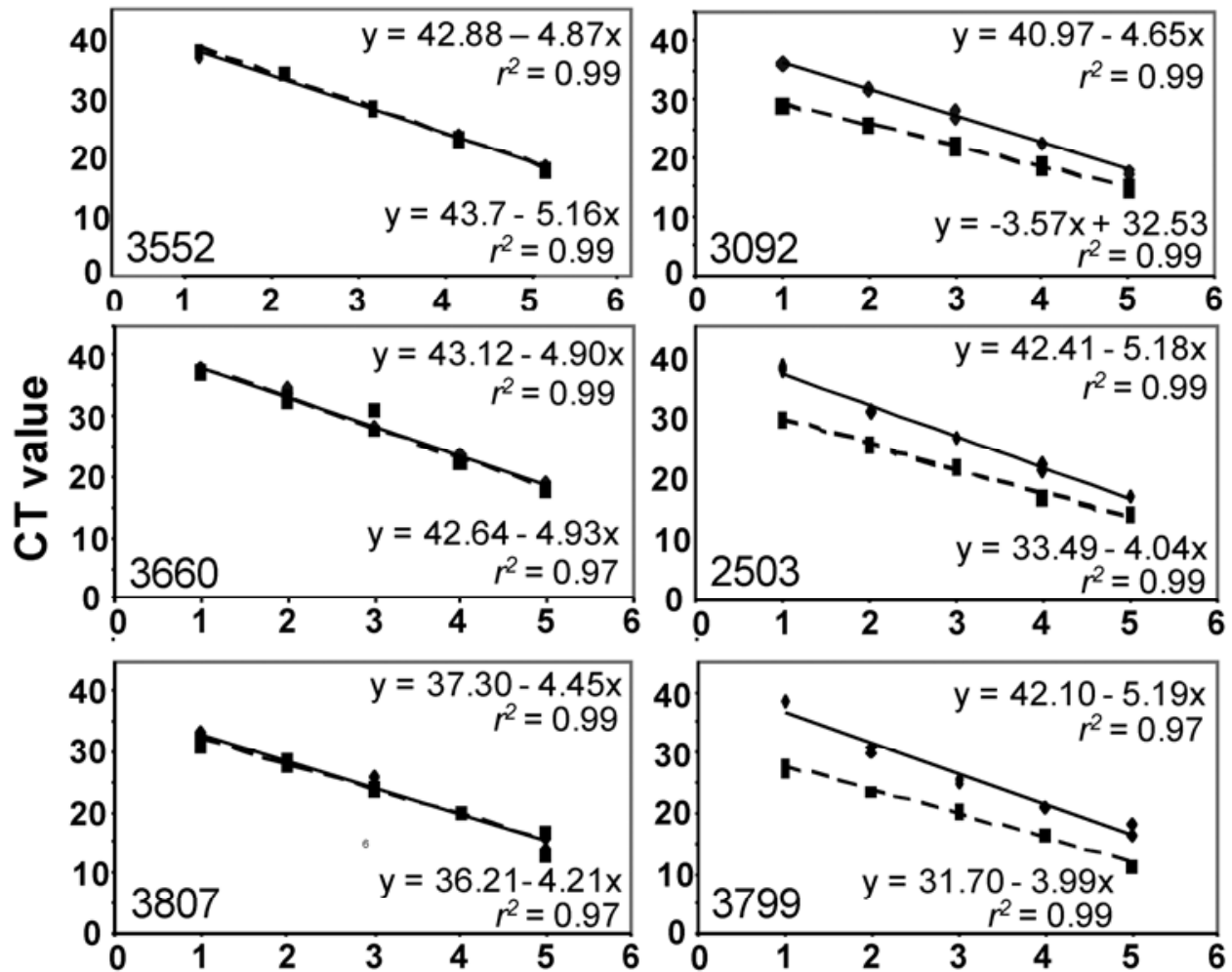

\section{DNA concentration $\left(\log _{10}(\mathrm{pg})\right)$}

Fig. 7. Linear regressions showing the relationship between DNA concentrations and cycle threshold $\left(\mathrm{C}_{\mathrm{T}}\right)$ values in quantitative polymerase chain reaction (qPCR) assays of six isolates of Fusicladium carpophilum (3552, 3660, 3807, 3092, 2503, and 3799) highly resistant to azoxystrobin. For each isolate, primer pairs CCF1-2/CCR1-2 (broken lines, regression line equation in lower right corner of each figure) and CCRF1/CCR1-2 (solid lines, regression line equation in upper right corner of each figure) were used in qPCR amplifications. 
QoI fungicides that were first registered on almond in 1999. Thus, a true baseline sensitivity range could not be determined. QoI fungicides were highly effective in controlling almond scab throughout the state prior to 2006. Therefore, widespread QoI resistance indicates that treatment failures can be attributed to fungicide resistance when only this one fungicide mode of action (i.e., the QoIs) was extensively used. Although samplings focused on locations where lack of efficacy of QoI fungicide treatments was reported, resistance was also present in other orchards. Currently, resistance to QoI fungicides in $F$. carpophilum occurs in many commercial orchards. The rapid increase in resistance to QoI compounds was likely due to their unprecedented effectiveness and subsequent extensive and often exclusive use for managing almond scab.

Two levels of azoxystrobin resistance, moderate and high, were identified, with $\mathrm{EC}_{50}$ values between 0.15 and $10 \mu \mathrm{g} / \mathrm{ml}$ or $>40$ $\mu \mathrm{g} / \mathrm{ml}$, respectively. Moderately resistant isolates were less common and were always found together with highly resistant isolates at an orchard location. Thus, it is not known whether field applications of QoI fungicides can still be effective in controlling scab that is caused by moderately resistant isolates of the pathogen alone. For some plant-pathogenic fungi studied by others, however, disease caused by moderately resistant isolates could be controlled satisfactorily using recommended field rates (22).

As previously established for many other plant pathogens $(3,9)$, high resistance to azoxystrobin in F. carpophilum was associated with a substitution of glycine with alanine at amino acid position 143 of the mitochondrial cytochrome $b$ gene. For the moderately resistant isolates, no mutations in the gene were detected between codons 122 and 212. Thus, previously described mutations at codon sites 129 and 137 conferring lower levels of resistance (10) could not be found. Efflux transporter-mediated resistance to QoI fungicides has been reported for several fungi, including Aspergillus nidulans (1) and Pyrenophora tritici-repentis $(19,20)$, and this mechanism could be explored for $F$. carpophilum in the future.

The frequency of highly resistant isolates could be accurately determined in laboratory mixtures of conidia with selected genotype ratios using primers we designed to target the G143A mutation in $F$. carpophilum. Resistance frequencies within pathogen populations as determined by qPCR closely correlated with the actual genotype ratios used in preparing the conidial suspensions. This demonstrated the potential usefulness of the designed approach in quantifying azoxystrobin resistance levels in field populations and, possibly, in providing fungicide use recommendations to growers.

To further substantiate this approach, resistance frequencies determined by two approaches were directly compared using infected almond fruit. Thus, fungal isolates that were obtained from scab lesions of individual fruit were evaluated for their QoI sensitivity using amended media, and bulked samples of the same lesions were subjected to the qPCR method. There was a very poor correlation between resistance frequencies obtained using the two methods. Frequencies using qPCR were mostly underestimated. In contrast, in a previous study with Alternaria spp. infecting pistachio, resistance frequencies over a wide range correlated closely using methods based on in vitro testing of fungicide sensitivity of isolates or based on the qPCR method (15).

One explanation that was considered for this lack of correlation in the current study is differences in growth inside host tissues between sensitive and highly resistant isolates of $F$. carpophilum. Thus, sensitive isolates may colonize scab lesions more extensively, leading to an overestimation of the frequency of sensitivity by qPCR. This hypothesis could not be further evaluated because of the difficulty of obtaining scab lesions in almond fruit inoculations in the field. No differences in growth of sensitive and highly resistant isolates on agar media, however, were observed (data not presented). Additionally, our competition experiments using conidial suspensions demonstrated that highly resistant isolates competed well in the presence of different amounts of sensitive and moderately resistant genotypes.
Another possible explanation for the lack of correlation between the methods is the presence of heteroplasmy in resistant isolates of the fungus. The presence of heterogeneous mitochondria in individual fungal isolates coupled with dominant or recessive gene expression of the resistance trait would result in differences between phenotypic and genotypic frequencies. In our study, regression lines of qPCR amplifications using serial dilutions of template DNA and primers targeting the G143A allele or the cytochrome $b$ gene were significantly different for three of the six isolates tested. This indicated the presence of heteroplasmy in these latter isolates. Amounts of amplicon in each case were lower using the primer pair targeting the G143A allele, consistent with underestimation of QoI resistance by the qPCR method in scab lesions in our studies and dominant expression of resistance. Isolates were randomly chosen for this test and the incidence of suggested heteroplasmy was high. Apparently, however, isolates chosen for our determination of QoI resistance frequencies in conidial mixtures, were all homoplasmic because qPCR data correlated closely with actual frequencies. Allele-specific PCR amplifications in Blumeria graminis f. sp. tritici previously demonstrated the presence of a mixed heteroplasmic population of QoI-sensitive and -resistant mitochondria in 2 of the 19 resistant isolates evaluated (8). Based on restriction digestion analysis of the partial cytochrome $b$ gene, heteroplasmy for QoI resistance was also detected in several cucumber and eggplant pathogens (12). Thus, mixed mitochondrial populations may be common among several plant-pathogenic fungi, and this needs to be considered when quantifying QoI resistance solely by qPCR.

Field observations indicate that QoI resistance in F. carpophilum is stable and persists in the absence of fungicide selection pressure. Similarly, our in vitro competition experiments demonstrated stability of the highly resistant genotype. Fitness of QoI-resistant isolates has also been found in several other fungi such as Magnaporthe oryzae (16) and Alternaria alternata (13) but examples of reduced fitness are also known (3). On almond in California, concurrently with development of QoI resistance in F. carpophilum, resistance has also emerged widely in Alternaria spp. populations causing Alternaria leaf spot (J. E. Adaskaveg, unpublished). The common occurrence of QoI resistance against two major diseases of almond and lack of highly effective management alternatives stimulated the development of new fungicide treatments but also led to increased awareness of fungicide resistance management. The use of fungicide rotations and of premixtures with two active ingredients that are both toxic to the pathogen is one effective strategy to cope with the challenge of disease control in commercial high-yield almond production in California.

\section{Acknowledgments}

We thank M. Vilchez, K. Nguyen, and N. Nguyen for assistance in determining in vitro fungicide sensitivities and the Almond Board of California for financial support of this research.

\section{Literature Cited}

1. Andrade, A. C., del Sorbo, G., Van Nistelrooy, J. G. M., and de Waard, M. A. 2000. The ABC transporter AtrB from Aspergillus nidulans mediates resistance to all major classes of fungicides and some natural toxic compounds. Microbiology 146:1987-1997.

2. Bartlett, D. W., Clough, J. M., Godwin, J. R., Hall, A. A., Hamer, M., and Parr-Dobrzanski, B. 2002. The strobilurin fungicides. Pest Manage. Sci. 58:649-662.

3. Fernández-Ortuño, D., Torés, J. A., de Vicente, A., and Perez-García, A., 2008. Mechanisms of resistance to QoI fungicides in phytopathogenic fungi. Intern. Microbiol. 11:1-9.

4. Fisher, E. E. 1961. Venturia carpophila sp. nov., the ascigerous state of the apricot freckle fungus. Trans. Br. Mycol. Soc. 44:337-342.

5. Förster, H., Connell, J. H., and Adaskaveg, J. E. 2009. Dormant treatments as a component of integrated management of almond scab caused by Fusicladosporium carpophilum. (Abstr.) Phytopathology 99:S36.

6. Förster, H., Connell, J. H., and Adaskaveg, J. E. 2009. QoI resistance in Fusicladosporium carpophilum populations from almond in California. (Abstr.) Phytopathology 99:S35.

7. Förster, H., Kanetis, L., and Adaskaveg, J. E. 2004. Spiral gradient dilution, a rapid method for determining growth responses and $50 \%$ effective concentration values in fungus-fungicide interactions. Phytopathology 94:163-170. 
8. Fraaije, B. A., Butters, J. A., Coelho, J. M, Jones, D. R., and Hollomon, D. W. 2002. Following the dynamics of strobilurin resistance in Blumeria graminis f. sp. tritici using quantitative allele-specific real-time PCR measurements with the fluorescent dye SYBR green I. Plant Pathol. 51:45-54.

9. Gisi, U., Sierotzki, H., Cook, A., and McCaffery, A. 2002. Mechanisms influencing the evolution of resistance to Qo inhibitor fungicides. Pest Manage. Sci. 58:859-867.

10. Grasso, V., Palermo, S., Sierotzki, H., Garibaldi, A., and Gisi, U. 2006. Cytochrome $b$ gene structure and consequences for resistance to Qo inhibitor fungicides in plant pathogens. Pest Manage. Sci. 62:465-472.

11. Ishii, H., Fraaije, B. A., Sugiyama, T., Noguchi, K., Nishimura, K., Takeda, T., Amano, T., and Hollomon, D. W. 2001. Occurrence and molecular characterization of strobilurin resistance in cucumber powdery mildew and downy mildew. Phytopathology 91:1166-1171.

12. Ishii, H., Yano, K., Date, H., Furuta, A., Sagehashi, Y., Yamaguchi, T., Sugiyama, T., Nishimura, K., and Hasama, W. 2007. Molecular characterization and diagnosis of QoI resistance in cucumber and eggplant fungal pathogens. Phytopathology 97:1458-1466.

13. Karaoglanidis, G. S., Luo, Y., and Michailides, T. J. 2011. Competitive ability and fitness of Alternaria alternata isolates resistant to QoI fungicides. Plant Dis. 95:178-182.

14. Kim, Y. S., Dixon, P., Vincelli, P., and Farman, M. L. 2003. Field resistance to strobilurin (QoI) fungicides in Pyricularia grisea caused by mutations in the mitochondrial cytochrome $b$ gene. Phytopathology 93:891-900.

15. Luo, Y., Ma, Z., Reyes, H. C., Morgan, D. P., and Michailides, T. J. 2007. Using real-time PCR to survey frequency of azoxystrobin-resistant allele A143 in Alternaria populations from almond and pistachio orchards in California. Pestic. Biochem. Physiol. 88:328-336.

16. Ma, B., and Uddin, W. 2009. Fitness and competitive ability of an azoxystrobin-resistant G143A mutant of Magnaporthe oryzae from perennial ryegrass. Plant Dis. 93:1044-1049.

17. Ma, Z., and Michailides, T. J. 2004. An allele-specific PCR assay for detecting azoxystrobin-resistant Alternaria isolates from pistachio in California J. Phytopathol. 152:118-121.

18. Ogawa, J. M., and English, H. 1991. Diseases of Temperate Zone Tree Fruit and Nut Crops. University of California, Division of Agriculture and Natural Resources, Oakland. Publ. 3345.

19. Reimann, S., and Deising, H. B. 2005. Inhibition of efflux transportermediated fungicide resistance in Pyrenophora tritici-repentis by a derivative of 4'-hydroxyflavone and enhancement of fungicide activity. Appl. Environ. Microbiol. 71:3269-3275.

20. Sierotzki, H., Frey, R., Wullschleger, J., Palermo, S., Karlin, S., Godwin, J., and Gisi, U. 2007. Cytochrome b gene sequence and structure of Pyrenophora teres and $P$. tritici-repentis and implications for QoI resistance. Pest Manage. Sci. 63:225-233.

21. Sierotzki, H., Parisi, S., Steinfeld, U., Tenzer, I., Poirey, S., and Gisi, U. 2000. Mode of resistance to respiration inhibitors at the cytochrome bc1 enzyme complex of Mycosphaerella fijiensis field isolates. Pest Manage. Sci. 56:833-841.

22. Sierotzki, H., Wullschleger, J., and Gisi, U. 2000. Point-mutation in cytochrome $b$ gene conferring resistance to strobilurin fungicides in Erysiphe graminis f. sp. tritici field isolates. Pestic. Biochem. Physiol. 68:107-112.

23. Zhang, Z., Zhu, Z., Ma, Z., and Li, H. 2009. A molecular mechanism of azoxystrobin resistance in Penicillium digitatum UV mutants and a PCRbased assay for detection of azoxystrobin-resistant strains in packing- or store-house isolates. Int. J. Food Microbiol. 131:157-161.

24. Zheng, D., and Köller, W. 1997. Characterization of the mitochondrial cytochrome b gene from Venturia inaequalis. Curr. Genet. 32:361-366. 